\section{International Scientific Journal Theoretical \& Applied Science}

p-ISSN: 2308-4944 (print) e-ISSN: 2409-0085 (online)

Year: 2015 Issue: 07 Volume: 27

Published: $30.07 .2015 \quad$ http://T-Science.org
Aliya Tajieva

$\mathrm{PhD}$, Head of the department Nukus State Pedagogical Institute, Uzbekistan aliya_tazhieva@mail.ru

Nargiza Babaniyazova assistant teacher, Nukus State Pedagogical Institute, Uzbekistan angel2357@mail.ru

SECTION 21. Pedagogy. Psychology. Innovations in the field of education.

\title{
EDUCATIONAL REFORMS IN THE REPUBLIC OF UZBEKISTAN IN OPERATION
}

Abstract: The article depicts the improvements in the educational sector in the Republic of Uzbekistan. The emphasis is given to the support by the government on the perfection of foreign language learning system. The researchers suggest their own ways of teaching foreign languages to the learners of academic lyceums and vocational colleges in the country.

Key words: Reorganization of the educational system, personnel training, continuous education, scientific and practical centre, Coordinating Council, educational standards, new curriculum, Modular Technology, national peculiarities.

Language: English

Citation: Tajieva A, Babaniyazova N (2015) EDUCATIONAL REFORMS IN THE REPUBLIC OF UZBEKISTAN IN OPERATION. ISJ Theoretical \& Applied Science 07 (27): 134-137.

Soi: http://s-o-i.org/1.1/TAS-07-27-23 Doi: crossef http://dx.doi.org/10.15863/TAS.2015.07.27.23

Today, in the Republic of Uzbekistan great attention is given to the radical reorganization of the educational system that will give an opportunity to raise it to the level of modern standards. In order to realize the aims and tasks put forward by the Law of the Republic of Uzbekistan "On Education" (1997) and the "National Programme of Personnel Training" (1997) the complex system of reorganizing the structure and the content of personnel training, proceeding from perspectives of the social, economic development of the society, contemporary achievements of science, culture, technique and technology are being created in the country. The National Programme for Personnel Training is being implemented in the country step by step. Within the framework of this Programme the system of continuous education is being developed, a system which starts with pre-school provision. The material and technical base of the education sector is strengthening, basic textbooks in the languages of peoples, living in the country are being published, the physical learning environment are improved, modern information technology are being used in the process of education.

New approaches in the system of education also influenced on the learning and teaching of foreign languages, as language is the major factor of person's development. The President of the Republic of Uzbekistan Islam Karimov highlighted the organization of a complex system of learning and teaching foreign languages in the country, focused on the upbringing of comprehensively developed, educated and intellectual young generation of people, who can meet the requirements of the time. After the Presidential Decree "On measures to further improve of foreign language learning system"(2012) a lot of projects have been done as an implementation of this important document. We can mention that from 2013/2014 academic year teaching of foreign languages, mainly English, started from the first grade of the primary school in the format of games and informal conversation lessons and since the second class schoolchildren learned the alphabet, studied grammar and developed speech skills. And regular training programs shown in the mass media are giving positive results not only in acquisition of knowledge and skills, but also in motivating uzbek children to foreign language learning. Within these short period of time in any part of our country we can meet parents who are proud of their children speaking English.

Therefore the necessary conditions for successful learning of foreign languages at all grades are being created in the country. The republican scientific and practical centre for developing innovative techniques of teaching foreign languages has been established at the Uzbek State University of World Languages due to the decree of the President 
ESJI (KZ)

SJIF (Morocco) $=\mathbf{2 . 0 3 1}$

of Uzbekistan «About measures on perfection of the activity of the Uzbek State University of World Languages»(2013). The centre is responsible for great deal of work, like carrying out scientific researches directed on working out and introducing of innovative techniques of teaching foreign languages to uzbek children at all grades of continuous education; developing educational standards on learning foreign languages; maintaining methodological support for educational institutions, preparing teachers and experts in the field of foreign language teaching, implementing modern methods of teaching foreign languages, monitoring the realization of requirements of the international standards of teaching foreign languages according to "Common European Framework of References: learning, teaching, assessing”.
For realization of these tasks there operating Coordinating Council in the country, which together with the ministries and departments, leading scholars and experts is engaged in working out the new educational standards providing concrete criteria to the level of knowledge on foreign languages at each grade, and also new curricula and programs for comprehensive schools, secondary special and professional education and higher educational institutions.

The decision of the Cabinet of Ministers of the Republic of Uzbekistan «On Adopting the State Educational Standards of Continuous Education in Uzbekistan (requirements to the content and level of learners on foreign languages)» (2013) has been implementing into practice since 2013-2014 academic year.

The learning of foreign languages in the system of continuous education in Uzbekistan.

\begin{tabular}{|c|c|c|c|}
\hline $\begin{array}{l}\text { Forms of Continuous } \\
\text { Education }\end{array}$ & Graduates & $\begin{array}{l}\text { CEFR } \\
\text { Level }\end{array}$ & Names of Levels \\
\hline \multirow{3}{*}{$\begin{array}{l}\text { General secondary } \\
\text { education }\end{array}$} & Graduates of primary schools & A 1 & Breakthrough \\
\hline & Graduates of 9 form & A 2 & Waystage \\
\hline & $\begin{array}{l}\text { Graduates of } 9 \text { form of state specialized } \\
\text { secondary schools of learning foreign } \\
\text { languages }\end{array}$ & A 2+ & Waystage \\
\hline \multirow{4}{*}{$\begin{array}{l}\text { Secondary specialized } \\
\text { and vocational training }\end{array}$} & $\begin{array}{l}\text { Graduates of academic lyceums with non- } \\
\text { language learning }\end{array}$ & & \multirow[t]{3}{*}{ Threshold } \\
\hline & Graduates of vocational colleges & & \\
\hline & $\begin{array}{l}\text { Graduates of academic lyceums with } \\
\text { language learning purpose }- \text { the second } \\
\text { foreign language. }\end{array}$ & B 1 & \\
\hline & $\begin{array}{l}\text { Graduates of academic lyceums with } \\
\text { language learning purpose }\end{array}$ & B 1+ & Threshold \\
\hline \multirow{4}{*}{ Higher education } & $\begin{array}{l}\text { Graduates of bachelor degree of non- } \\
\text { philological departments }\end{array}$ & \multirow{3}{*}{ B 2} & \multirow[t]{3}{*}{ Vantage } \\
\hline & $\begin{array}{l}\text { Graduates of bachelor degree of } \\
\text { philological departments- the second } \\
\text { foreign language }\end{array}$ & & \\
\hline & $\begin{array}{l}\text { Graduates of master's degree of non- } \\
\text { philological departments }\end{array}$ & & \\
\hline & $\begin{array}{l}\text { Graduates of bachelor degree of } \\
\text { philological departments }\end{array}$ & C 1 & $\begin{array}{l}\text { Effective Operational } \\
\text { Proficiency }\end{array}$ \\
\hline
\end{tabular}

Taken from "The State Educational Standards of Continuous Education in Uzbekistan (requirements to the content and level of learners on foreign languages".

Further we'd like to write about what is being done according to this educational standard in the example of academic lyceums and vocational colleges. A great number of teaching aids, coursebooks are being created in the country, as we need well-founded methodological approaches for 
each grade in order to develop the learners knowledge and skills. There designed a new curriculum for these educational establishments. In a new curriculum the hours given to learning foreign languages at the academic lyceums and vocational colleges are increased from 180 to 250 .

The general aim of the subject "Foreign Languages"(5) at the academic lyceums is to develop learners' ability to use the appropriate language in different social contexts and to express viewpoints on political, economic and social life of Uzbekistan and abroad countries. According to the Educational Standard, learners of academic lyceums and vocational colleges should also acquire knowledge and abilities in the future professional sphere and be able to interact with others on professional topics using the appropriate discourse.

In order to reach the aim and fulfill tasks put forward before education every teacher, every researcher in the field of methodology should think of finding the effective ways of teaching children. As a researcher, in learning foreign languages we are suggesting and experimenting the use of modular technology with the learners of academic lyceums and vocational colleges in our country.

Modular Technology is not a new approach in teaching today. First it was used at the end of 1960s in the USA, England and Canada. Later Russian scholars (E.M.Durko, V.M.Garaev, A.A.Gutsinsky, S.A.Kashin, S.I.Kulikov, S.I.Samigina, N.V.Shumyakova, Y.F. Timofeeva, Y.A.Ustinyuk) contributed to the development and realization of this technology in their country. They investigated, experimented and proved the effectiveness of the approach in learning process. Analyzing scholars' viewpoints, calculating the results achieved by us we came to the conclusion that modular technology can be successfully used with our learners of academic lyceums and vocational colleges.

One of the reasons of suggesting this method of teaching is that learners of these educational establishments are students who have developed their own way of study and are more eager to learn by themselves than under the teacher's control. They do not want to be unaware of the tricks of learning, they do not want to simply do whatever the teacher tells them to do, having no means to question the wisdom thereof. And modular training gives them opportunity to find out the necessary knowledge and develop skills need for their future professions themselves.

The second reason is that non-traditional way of learning may motivate them to work as these learners need to know the reasons why they are required to act in particular ways. In entering to every module students can be given the purpose and reasons why particular ways of acting are considered desirable. Modular technology is a specific method of approaching the aim, modes of operation for achieving a particular end, planned designs for controlling and manipulating information. "Teaching through module is a self - taking in bundle managing one particular topic/ unit. It could be utilized within any setting helpful to the learner and may be finished at the learner's own particular pace" [9, p.103].

The third reason is that the results student achieved can arouse his motivation to learning and a sense of self identity, as the feelings of competence and self-effecacy can be gained by working out his own solutions to problems. Students with a strong sense of self identity have been described as less susceptible to peer pressure, having a high level of self-acceptance, optimistic and firm in their belief that they are in control of their own destinies. (Erikson 1968) The importance of our lessons is in fostering this sense of personal identity by encouraging learners to make decisions for themselves and helping them to express their individuality in constructive ways. Someone who has developed a strong sense of personal identity, personal autonomy, initiative and industry should be in a good position in society.

Modular training consists of several modules each of which has his own action plan, bank of information, tasks to complete and methodological support to work with. P.A.Yutsavichene considers that it can give the learner opportunity to work with individual program suggested to him and fulfill tasks in his own way. This kind of way helps students to become self-driven independent learners, they become fully aware of their own strengths, weaknesses, preferences and be able to capitalize on that metacognition through the use of appropriate actions. This leads to awareness-action relationship, one of the fundamental to all human learning and especially to acquiring complex skills like foreign languages. When learners are aware of their own capacities, they can efficiently adopt pathways to success.

This means that one of the best ways of getting students involved into foreign language learning is to offer them the opportunity to develop their own strategies for success. So, Modular technology is an effort to fill class hours with fascinating material which enable learners to eventually become independent of classrooms-that is, to become autonomous learners. Modular education is a more flexible educational approach that increases teaching efficiency by making use of especially other teaching forms. [8, p.1388]

We hope that this way of learning helps us prepare a good language learner, who is able to find their own way of learning, can organize information about the language, make their own opportunities for practice, vary language according to the situation and make intelligent guesses.

In conclusion we'd like to say that we should prepare in our country the methods of intensive 


\begin{tabular}{|c|c|c|c|c|c|c|}
\hline Impact Factor: & $\begin{array}{l}\text { ISRA (India) } \\
\text { ISI (Dubai, UAF } \\
\text { GIF (Australia) } \\
\text { JIF }\end{array}$ & $\begin{array}{l}=1.344 \\
=\mathbf{0 . 8 2 9} \\
=\mathbf{0 . 3 5 6} \\
=1.500\end{array}$ & $\begin{array}{l}\text { SIS (USA) } \\
\text { PИHЦ (Russia) } \\
\text { ESJI (KZ) } \\
\text { SJIF (Morocco) }\end{array}$ & $\begin{array}{l}=0.912 \\
=0.179 \\
=1.042 \\
=2.031\end{array}$ & ICV (Poland) & $=6.630$ \\
\hline
\end{tabular}

foreign language learning based on our national peculiarities. Only in this way we can provide uzbek children with all the necessary conditions for the access to this amazing world of foreign languages [1, p.9].

\section{References:}

1. Karimov IA (1997) "Harmoniously developed generation is the basis of progress of Uzbekistan. Tashkent: Uzbekistan,1997.

2. (2012) The decree of the President of Uzbekistan I.A.Karimov № 1875 "On measures to further improve of foreign language learning system", December, 10, 2012.

3. (2013) The decree of the President of Uzbekistan № 1971 «About measures on perfection of activity of the Uzbek State University of World Languages», May, 23, 2013.

4. (2013) The decision of the Cabinet of Ministers of the Republic of Uzbekistan № 124«On Adopting the State Educational Standards of Continuous Education in Uzbekistan (requirements to the content and level of learners on foreign languages)», May, 8, 2013.
5. (2013) The Programme on Foreign Languages for Academic Lyceums and Vocational Colleges. Tashkent, 2013

6. Ericksen EH (1968) Youth and Crisis. New York: Norton, 1968.

7. Garaev VM, Kulikov SI, Durko EM (1987) The Principles of Modular Training. Vestnik visshey shkoli, Moscow, 1987. №2. - pp.132-135.

8. Tanrisiver S, Erisen Y (2009) The evaluation of Modular Training Programmes developed for the "modernization of vocational and technical training project.Procedia Social and Behavioral Sciences 1.2009. - pp.1384-1388.

9. Sadik S, Zamir S (2014) Effectiveness of Modular Approach in Teaching at University Level.Journal of Education and Practice, vol.5, №17, 2014.

10. Yutsavichene PA (1989) The Basis of Modular Training, Vilnius. 